International Journal of Instruction e-ISSN: 1308-1470 • www.e-iji.net

Article submission code: 20200213164252

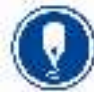

Received: $13 / 02 / 2020$ Revision: 31/12/2020
July $2021 \bullet$ Vol.14, No.3

p-ISSN: 1694-609X

pp. 519-534

Accepted: 26/01/2021

OnlineFirst: 03/06/2021

\title{
Effectiveness of Problem-Based Learning Combined with Computer Simulation on Students' Problem-Solving and Creative Thinking Skills
}

\section{Mariati Purnama Simanjuntak}

Science Education Study Program, Universitas Negeri Medan, Indonesia, mariatipurnama@unimed.ac.id

\section{Juniar Hutahaean}

Physics Education Study Program, Universitas Negeri Medan, Indonesia, junhut@unimed.ac.id

\section{Nurliana Marpaung}

Science Education Study Program, Universitas Negeri Medan, Indonesia, nurlianamarpaung@unimed.ac.id

\section{Dewi Ramadhani}

Physics Education Study Program, Universitas Negeri Medan, Indonesia, dewiramadhani47@gmail.com

\begin{abstract}
This study is aimed to investigate the effectiveness of problem-based learning combined with simulation on students' problem-solving and creative thinking skills. By employing a quasi-experimental design, this study used essay and problem-based tests as the instruments to evaluate problem-solving and creative thinking skills of 192 students. These students were categorized into three groups: experimental group I $(n=68)$ receiving instruction using problem-based learning combined with simulation, experimental group II $(n=60)$ receiving instruction with problem-based learning only, and control group $(n=64)$ receiving instruction with a conventional method. Using a multivariate analysis of covariance, the results revealed that problem-solving and creative thinking skills taught by problem-based learning combined with simulation were significantly improved as compared to those in experimental group II and control group. In addition, a positive relationship was identified between students' problem-solving skills and their creative thinking skills. Ultimately, this study shows that instruction using problem-based learning combined with simulation method is much more effective than using either problem-based learning only or a conventional teaching method.
\end{abstract}

Keywords: simulation, creative thinking, problem-solving, problem-based learning, skill

Citation: Simanjuntak, M. P., Hutahaean, J., Marpaung, N., \& Ramadhani, D. (2021). Effectiveness of Problem-Based Learning Combined with Computer Simulation on Students' Problem-Solving and Creative Thinking Skills. International Journal of Instruction, 14(3), 519-534. https://doi.org/10.29333/iji.2021.14330a 


\section{INTRODUCTION}

Effective teaching and learning is imperative to prepare students with competencies and skills required to acclimate industrial revolution 4.0 in the $21^{\text {st }}$ century. According to earlier studies (See, et al., 2015), certain skills that we could obtain from learning process are creative and innovative thinking, analyzing information, problem-solving, using media and technology, and life and career skills. Education in industrial revolution era requires the use of technology such as computer which is expected to shift the mindset of teaching from teacher-centered to student-centered. Teacher centered learning involving lecture method, question and answer method, task, and discussion with the use of blackboard as the only media in learning process has generated the lack of students' involvement in teaching and learning, which is known as conventional learning (Wahyu, et al., 2017). The use of technology in education such as game, virtual reality, and computer simulation had developed in the past few decades (Makransky, et.al., 2019; Rutten, et al., 2012; Ulukök \& Sari, 2016). Simulation can be used to enhance teaching and to facilitate students' active engagement, as they could easily understand information when learning science illustrated with simulation (Manunure, et al., 2019). The simulation also could train students' problem-solving, innovation, and creativity skills (Vlachopoulos \& Makri, 2017). Therefore, simulation is highly important in teaching and learning process.

This study focused on investigating the development of problem-solving and creative thinking skills of students taught by problem-based learning (PBL) combined with simulation, the two sets of skills are fundamental in $21^{\text {st }}$-century society. Problemsolving skills refer to a set of cognitive-behavioral activities by which a person attempts to discover or to develop an effective solution to real-life problems. Problem-solving steps according to Nezu, et al., (2013) are problem definition, generation of alternatives, decision making and solution implementation and verification. Problem-solving is a higher-order thinking skill, which needs creative thinking, critical thinking, and decision making (Wanya, 2016). In addition, an individual with good problem-solving skills is able to answer a problem after correctly implementing the solution and evaluating the reasonableness of the answer (Wanya, 2016). Creative thinking can be described as the whole set of cognitive activities that individuals use against a specific object, problem and situation, or an effort towards a particular event and the problem according to an individual's ability (Birgili, 2015). Kampylis and Berki (2014) argued that creative thinking is the process of thinking which allows students to apply their imagination in order to generate and evaluate their ideas, questions, and hypotheses. Indicators of creative thinking in research are fluency, flexibility, originality, and elaboration (Syaibani, et al., 2017). The aforementioned concerns show that it is crucial to develop new initiatives to foster students' problem solving and creative thinking skills in learning science.

\section{Problem statement}

Most of Indonesians students' problem-solving and creative thinking skills are relatively low (Rahmawati \& Taylor, 2019). One of the reasons for this fact is the teaching method dominantly based on teacher-centered which emphasizes only the mathematical formula 
(Sahyar et al., (2017). The teachers frequently teach factual knowledge and rarely connect a learning topic to problems or phenomena in real-life and do not conduct experiments to carry out further investigations in a problem-solving process. Mustofa \& Hidayah (2020) argued that teachers should not only teach factual knowledge but also improve the students' skills like creative thinking. Mariati, et al., (2017) argued that the low students' problem-solving and creative thinking skills might occur because they were still accustomed to engage with problems process that emphasizes mathematical formulas rather than connecting the concepts through scientific problems. As a result, they could not develop their creative thinking skills while solving a given problem. In addition, when encountering a problem, they lack to focus on the problem, could not make planning for solutions to the problem, and do not understand how to solve the problem. Sahyar et al., (2017) and Shisigu et al., (2018) found that the emergence of low problem-solving skills due to learning process that remains emphasize teacher-centered instruction in which students are frequently passive in the classroom and engage only if teachers need their involvement. Commonly, students also exhibit difficulties to determine which concept was correct and are confused concerning the application of principles, theories, laws, and formulas to answer and solve physics problems.

\section{Research Focus}

One of the teaching methods that can be used to improve students' problem-solving and creative thinking skills is problem-based learning (PBL). PBL is an effective learning method that encourages students to learn through authentic problem-solving (Lee et al., 2017; Marra et al., 2014). The goal of implementing PBL is to help students develop their creative thinking and problem-solving skills (Sihaloho et al., 2017). The given problem provides an opportunity for learners to be creative and innovative. The students' problem-solving skills who were taught with the PBL method were better than those taught with the conventional method (Argaw et al., 2017; Sihaloho et.al, 2017). Some studies also found that the results of implementing PBL could improve students' the creative thinking skills ( Ersoy \& Baser, 2014; Nuswowati et. al., 2017; Siew, et. al, 2015; Ulger, 2016).

Learning is a communication process to deliver information from sources to the recipients that need media. The use of technology-based learning media has a very positive impact on the ability and willingness of students to follow the learning process. One of the technology-based media that has a positive impact on learning is a computer simulation. Simulation is a representation of a system using the same concept as the system which is made using computer programming (McHaney, 2009). Computer-based simulations (CBS) are able to present the dynamics and complexity of certain concepts that are very difficult to explain using words, equations, or experiments (Jane, et al., 2017).

Based on the aforementioned concern, simulation is very suitable for teaching and learning physics, it can help students learn and understand difficult physics concepts. The nature of physics is mostly an abstract concept that often makes students think physics is difficult and boring. By using simulation, many difficult physics topics can be taught easier and more enjoyable, resulting on the improvement of students' 
achievement (Bozkurt \& Ilik, 2010). Koray \& Abdullah (2013) argued that PBL using simulation in physics learning could improve students' ability because it could illustrate the abstract physical concepts into more concrete representations. In this present study, a Microsoft Excel spreadsheet simulation with a Visual Basic Application (VBA) is used because this simulation can illustrate graphs on the screen, show accurate calculations, and make the learning process more interesting. Tambade (2011) argued that the simulation programming is efficient. In addition, simulation using spreadsheet media is very effective in helping students to learn since it provides an opportunity for students to change the variables.

Combining PBL and simulation is expected as an innovative learning method not only to improve the student's problem-solving but also creative thinking skills. The previous study showed that problem-based learning using computer simulations had a positive impact on the problem-solving and creative thinking of students (Arias et al., 2020; Nuswowati, 2017; Sarabando et al., 2014; Siew et al., 2015). Beal \& Stevens, 2011 stated that simulations could help students to build scientific problem-solving skills, especially when the environment is designed to give students some guidelines for solving problems. Sulaiman, (2013) stated that PBL could be trusted to help the development of creative thinking skills among students in various fields of education, especially in learning physics. Sihaloho, et al. (2017) found that creative thinking and problem-solving skills of students taught with PBL were better than those taught with conventional learning. Although a few studies have investigated the great impact of using PBL combined with simulation, the studies recommend expanding similar investigation in different contexts. Accordingly, this study is aimed to investigate the effectiveness of PBL models with simulations on students' problem-solving and creative thinking skills. The research questions in this study are given as follows:

1. Is the implementation of PBL combined with computer simulation effective on improving students' problem-solving and creative thinking skills?

2. Is there any relationship between problem-solving and creative thinking skills?

\section{METHOD}

\section{Research Design}

This study adopted a quasi-experimental design to understand how students learned science using PBL combined with computer simulation, PBL only and conventional method. The pretest and posttest were done to examine the effectiveness of three different methods related to students' problem-solving and creative thinking skills.

\section{Participants}

The population of this study were 21 classes with a total number of 740 tenth-grade students from two senior high schools in Medan. Six classes were selected by cluster random sampling technique which were 3 classes from each school with a total number of 192 students, all of whom were taking the physic course, were participated in this study. These students were randomly assigned into three groups, the experimental group I (68 students) that received PBL using simulation, experimental group II (60 
students) that received PBL, and one control group (64 students) that received conventional method. The number of students in each class was ranged from 30-34 students. These students were examined before and after the intervention. The participants of this study had not previously learned the topics before the intervention. The experimental group I and II received PBL using computer simulation and PBL only, respectively, while the control group received conventional instruction, which mainly adopted a didactic teaching approach with textbooks.

\section{Computer Simulation}

Two physic topics (i.e., simple harmonic motion and impulse and momentum) were selected to be taught during the instructions. A problem-based worksheet was developed to guide students in solving the problems. The worksheet lists tools, materials, procedures, and guiding questions. The teacher designed and operated computer simulations that support students in solving the problem in each worksheet. The representative of the computer simulations for pendulum oscillation and impulse and momentum are shown in Figure 1.
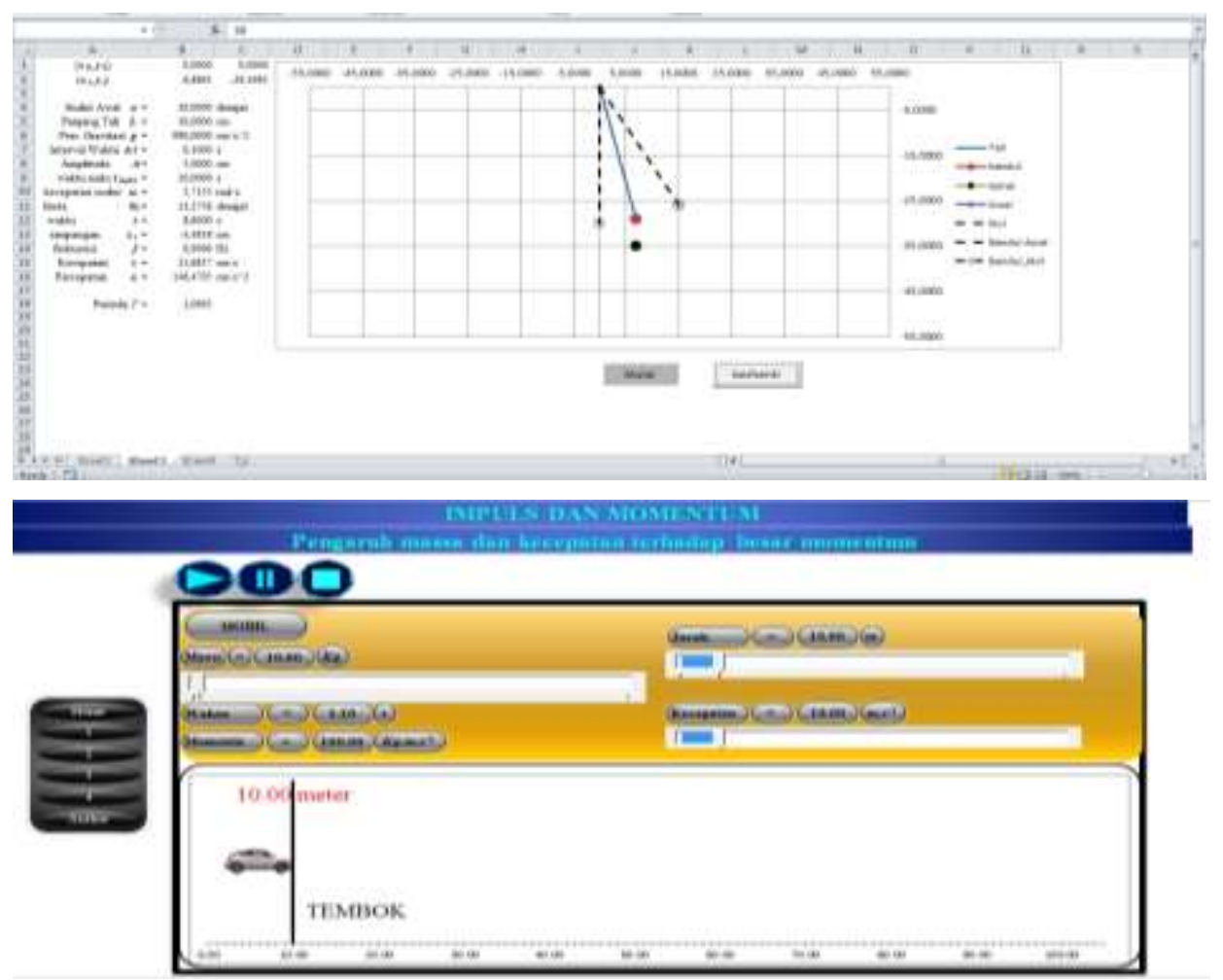

Figure 1

Simulation for harmonic motion (top) and impulse and momentum (bottom) 


\section{Intervention}

In the experimental group I, the students were guided with five phases of PBL using computer simulation. The students in experimental II were involved learning process with only PBL. Students in the control group were taught by the conventional method (see Table 1).

The initial stage of PBL is to orient students with authentic problems. This stage provoked students to think of the way that can be done to find solutions for the problem through the process of investigation. When a problem was presented, students were required to define the problem in the form of problem clarification.

The second stage is organizing students to learn by making a learning group that engages collaboration and interaction among the group members to exchange new ideas. The ideas expressed by each group member could stimulate others to build their ideas and further improve their creative skills.

In the third stage, students conducted individual and group investigations. They conducted experiments in groups as the experimental procedure was not given in detail so that students were required to find alternative solutions for problems and to make decisions if the solutions had not been or had been solved (fluency and flexibility). Students with their groups were required to convey their ideas and new ideas (encouraging originality) based on the given problems and determine the alternative problem-solving process by thinking about many possible strategies to solve the identified problems. After students conducted experiments, the results of the experiments were compared with computer simulations. Based on the simulations, students would realize whether their solution was aligned with the concept of physic or not. The simulations are crucial to motivate and make them more active because the simulations help to visualize an abstract physical concept into more concrete forms, allowing clearer and more detailed. The computer simulation directs students to solve problems based on the order of problem-solving process.

The fourth stage is presenting the results. This stage allows students to present their work in the form of problem-solving process and have a chance to know other alternative solutions offered by their classmates. The differences of solution from each student can train the students' creative thinking skills in terms of fluency and flexibility. Interaction among the groups generates the creation of new ideas (originality).

The fifth stage is evaluating the results of problem-solving process. The results of problem-solving process obtained by each group were then evaluated for accuracy through computer simulations and teaching materials provided. 
Table 1

Learning design for three groups

\begin{tabular}{|c|c|c|c|c|c|}
\hline \multicolumn{2}{|c|}{ PBL with computer simulation } & \multicolumn{2}{|l|}{ PBL } & \multicolumn{2}{|l|}{ Conventional } \\
\hline Teacher & Students & Teacher & Students & Teacher & Students \\
\hline \multicolumn{2}{|c|}{$\begin{array}{l}\text { Orienting students with authentic } \\
\text { problems }\end{array}$} & \multicolumn{2}{|c|}{$\begin{array}{l}\text { Orienting students with authentic } \\
\text { problems }\end{array}$} & & \\
\hline $\begin{array}{l}\text { Presents a simple } \\
\text { problem }\end{array}$ & $\begin{array}{l}\text { Listening and } \\
\text { understanding the } \\
\text { problem }\end{array}$ & $\begin{array}{l}\text { Presenting a } \\
\text { simple problem }\end{array}$ & $\begin{array}{l}\text { Listening and } \\
\text { understanding the } \\
\text { problem }\end{array}$ & $\begin{array}{l}\text { Introducing } \\
\text { the topic } \\
\text { Gives an } \\
\text { example and }\end{array}$ & $\begin{array}{l}\text { Listening teacher's } \\
\text { lecture } \\
\text { Understand } \\
\text { Learn how to solve }\end{array}$ \\
\hline \multicolumn{2}{|c|}{ Organizing student to learn } & \multicolumn{2}{|c|}{ Organizing student to learn } & problem & problem \\
\hline $\begin{array}{l}\text { Makes up groups } \\
\text { Shares worksheet }\end{array}$ & $\begin{array}{l}\text { Forming group } \\
\text { learning } \\
\text { Accepting the } \\
\text { worksheet }\end{array}$ & $\begin{array}{l}\text { Making up } \\
\text { groups } \\
\text { Sharing } \\
\text { worksheet }\end{array}$ & $\begin{array}{l}\text { Forming group } \\
\text { learning } \\
\text { Accepting the } \\
\text { worksheet }\end{array}$ & $\begin{array}{l}\text { Asks } \\
\text { student to } \\
\text { solve the } \\
\text { problem at }\end{array}$ & $\begin{array}{l}\text { Solving the problem } \\
\text { at backbroad }\end{array}$ \\
\hline \multicolumn{2}{|c|}{ Individual and group investigations } & \multicolumn{2}{|c|}{ Individual and group investigations } & blackboard & \\
\hline $\begin{array}{l}\text { Guiding students to } \\
\text { conduct } \\
\text { experiment } \\
\text { according to the } \\
\text { problem to be } \\
\text { solved and to take } \\
\text { steps to solve the } \\
\text { problem } \\
\text { Presents computer } \\
\text { simulation to guide } \\
\text { students to solve } \\
\text { the problem } \\
\text { Asks each group to } \\
\text { discuss result of } \\
\text { their observation }\end{array}$ & $\begin{array}{l}\text { Conducting } \\
\text { experiment and write } \\
\text { the steps to solve the } \\
\text { problem in details } \\
\text { Watching the } \\
\text { computer simulation } \\
\text { and finding solution } \\
\text { Discussing the results } \\
\text { of the observation to } \\
\text { get idea to solve } \\
\text { problem }\end{array}$ & $\begin{array}{l}\text { Guiding students } \\
\text { to conduct } \\
\text { experiment based } \\
\text { on the problem to } \\
\text { be solved at the } \\
\text { worksheet } \\
\text { Asking each group } \\
\text { to discuss result of } \\
\text { the observation }\end{array}$ & $\begin{array}{l}\text { Conducting } \\
\text { experiment } \\
\text { according to } \\
\text { worksheet } \\
\text { Discussing the } \\
\text { results of the } \\
\text { observation to get } \\
\text { idea to solve } \\
\text { problem }\end{array}$ & & \\
\hline \multicolumn{2}{|l|}{ Presenting the work } & \multicolumn{2}{|c|}{ Presenting the work } & & \\
\hline $\begin{array}{l}\text { Asking each group } \\
\text { to present their } \\
\text { observation to other } \\
\text { groups } \\
\text { Presenting the result } \\
\text { obtained by } \\
\text { computer simulation } \\
\text { as a comparison } \\
\text { with students' } \\
\text { observation }\end{array}$ & $\begin{array}{l}\text { Presenting the results } \\
\text { of the observation } \\
\text { Comparing results of } \\
\text { observation with } \\
\text { computer simulation }\end{array}$ & $\begin{array}{l}\text { Asking each } \\
\text { group to present } \\
\text { the results of their } \\
\text { observation }\end{array}$ & $\begin{array}{l}\text { Presenting the } \\
\text { results of } \\
\text { observation to } \\
\text { other groups }\end{array}$ & & \\
\hline \multicolumn{2}{|c|}{ Evaluating the solution } & \multicolumn{2}{|c|}{ Evaluating the solution } & & \\
\hline $\begin{array}{l}\text { Helping students in } \\
\text { reviewing the steps } \\
\text { of problem-solving } \\
\text { and revise the } \\
\text { results of students' } \\
\text { observation }\end{array}$ & $\begin{array}{l}\text { Listening to the } \\
\text { teachers' } \\
\text { explanation of } \\
\text { problem-solving and } \\
\text { explain the } \\
\text { differences in the } \\
\text { results obtained }\end{array}$ & $\begin{array}{l}\text { Helping students in } \\
\text { reviewing the steps } \\
\text { of problem-solving } \\
\text { and revise the } \\
\text { results of students' } \\
\text { observation }\end{array}$ & $\begin{array}{l}\text { Listening to the } \\
\text { teacher review the } \\
\text { problem-solving } \\
\text { with the correct } \\
\text { concepts }\end{array}$ & & \\
\hline Making conclusion & $\begin{array}{l}\text { Listening to the } \\
\text { conclusion }\end{array}$ & & & $\begin{array}{l}\text { Evaluating } \\
\text { the students' } \\
\text { task } \\
\text { Making } \\
\text { conclusion } \\
\text { Giving } \\
\text { assigment }\end{array}$ & $\begin{array}{l}\text { Listening and } \\
\text { undestanding the } \\
\text { explanation } \\
\text { Listening to } \\
\text { conclusion } \\
\text { Writing the } \\
\text { assigment }\end{array}$ \\
\hline
\end{tabular}

International Journal of Instruction, July $2021 \bullet$ Vol.14, No.3 


\section{Instrument and Procedures}

The research instruments of essay and problem-based tests were used to measure problem-solving and creative thinking skills. Before the intervention process, students were given a pretest to measure their understanding of the concept. In the end of the intervention, a post-test, an essay, and problem-solving tests, were given to examine the students' problem-solving skills and creative thinking skills. The problem-solving tests consisted of 10 items, developed by Nezu, et.al (2013), wherein each solution follows the steps of problem-solving including problem definition, generation of alternatives, decision making, and solution implementation and verification. In addition, the creative thinking skills tests were measure based on some indicators representing creative thinking skills such as fluency, flexibility, originality, and elaboration. Each item of the indicators for problem-solving and creative thinking skills tests has to be completed within 10 minutes. The grid of test instruments for problem-solving and creative thinking skills are presented in Table 2 and Table 3 , respectively.

Table 2

Grid of test instruments for problem solving skill

\begin{tabular}{llll}
\hline No & Indicator & Sub Topic & Items \\
\hline 1 & Problem definition & Simple pendulum & 1 and 5 \\
\hline 2 & Generation of alternatives & Oscillation and spring & 2,3 and 4 \\
\hline 3 & Decision making & Impuls & 6 and 7 \\
\hline 4 & Solution implementation and verification & Momentum & 8,9 and 10 \\
\hline
\end{tabular}

Table 3

Grid of test instruments for creative thinking skill

\begin{tabular}{lllll}
\hline No & Indicator & Description & Sub Topic & Items \\
\hline 1 & Fluency & $\begin{array}{l}\text { Generating ideas or } \\
\text { alternative solution for a } \\
\text { problem. }\end{array}$ & $\begin{array}{l}\text { Simple pendulum and spring } \\
\text { oscillation } \\
\text { Impulse }\end{array}$ & $\begin{array}{l}1 \text { and } 2 \\
3\end{array}$ \\
\hline 2 & Flexibility & $\begin{array}{l}\text { Generating several ideas } \\
\text { with many possible } \\
\text { approaches }\end{array}$ & $\begin{array}{l}\text { Spring oscillation } \\
\text { Impulse }\end{array}$ & 4 \\
& & & 5 and 6 \\
\hline 3 & Originality & $\begin{array}{l}\text { Generating new ideas that } \\
\text { never though before }\end{array}$ & $\begin{array}{l}\text { Spring oscillation } \\
\text { Momentum }\end{array}$ & 7 \\
\hline 4 & Elaboration & $\begin{array}{l}\text { Generating answers in } \\
\text { details }\end{array}$ & $\begin{array}{l}\text { Simple pendulum } \\
\text { Momentum }\end{array}$ & 8 \\
\hline
\end{tabular}

\section{Data Analysis}

A pretest was employed to examine students' prior problem-solving and creative thinking skills while a posttest was used to examine the effectiveness of the intervention in the three classes on problem-solving and creative thinking skills. Quantitative data collected from the pretest and post-test measuring the problem-solving and creative thinking skills were analyzed to examine the effect of treatments in the established three groups. A one-way multivariate analysis of variance (MANOVA) was performed to 
analyze the data. The prerequisite tests including multivariate normality test and homogeneity test of covariance matrix were done by skewness and Box's M test $(F$ $(0.177)>p(0.01))$, respectively (Putich \& Stevens, 2016).

IBM SPSS for Windows was used to analyze the data with a significant level $p<0.05$. Percentage of improvement for problem-solving and creative thinking skills were analyzed by performing the average score of normalized gain ( $\mathrm{N}$ - Gain):

$$
g=\frac{\text { Posttest average }- \text { pretest average }}{\text { Maximum score }- \text { pretest average }}
$$

The $\mathrm{N}$-gain values $(\langle\mathrm{g}\rangle)$ of $\langle\mathrm{g}\rangle \geq 0.7,0.3 \leq<\mathrm{g}\rangle<0.7$ and $\langle\mathrm{g}\rangle \leq 0.3$ are categorized into criteria of high, medium, and low, respectively.

\section{FINDINGS}

The average value of the pretest and posttest of solving skills and creative thinking are listed in Table 4. The results showed that the average scores of pretests for problemsolving and creative thinking skills in those three groups are similar. However, there are significant differences on average scores for the posttest after the intervention. In addition, the results showed that there is a significant difference concerning the percentages of improvement (N-gain) on problem-solving and creative thinking skills among the three groups. Students in the experimental I group exhibited the highest percentages of improvement for problem-solving and creative thinking skills were in the experimental I group (i.e., $56 \%$ and $68 \%$, respectively). On the other hand, the lowest percentages were in the control group (i.e., $33 \%$ and $51 \%$, respectively).

Table 4

Descriptive statistics for problem-solving and creative thinking skills

\begin{tabular}{llllllll}
\hline \multirow{2}{*}{ Variable } & Group & Pretest & \multicolumn{3}{c}{ Postest } & N-gain & Criteria \\
\cline { 3 - 7 } & & Mean & SD & Mean & SD & $(\%)$ & \\
\hline \multirow{2}{*}{$\begin{array}{l}\text { Problem- } \\
\text { solving }\end{array}$} & Experimental I & 52.78 & 9.63 & 79.34 & 8.47 & 56 & Medium \\
\cline { 2 - 7 } & Experimental II & 52.59 & 7.83 & 72.00 & 7.72 & 41 & Medium \\
\cline { 2 - 7 } $\begin{array}{l}\text { Creative } \\
\text { thingking }\end{array}$ & Control group & 52.28 & 6.24 & 68.25 & 10.50 & 33 & Low \\
\cline { 2 - 7 } & Experimental I & 22.45 & 13.28 & 75.00 & 9.12 & 68 & Medium \\
\cline { 2 - 6 } & Control group & 22.06 & 7.68 & 70.57 & 10.81 & 62 & Medium \\
\hline
\end{tabular}

Table 5 shows the $\mathrm{N}$-gain score for each indicator of problem-solving and creative thinking skills. The highest scores were in the group implementing PBL combining with computer simulations while the lowest scores were in the group implementing the conventional teaching method. Furthermore, concerning students' problem-solving skills in the experimental group, the highest $\mathrm{N}$-gain score was identified in the indicator of the generation of alternatives $(83 \%)$ while the lowest score was found in the indicator of solution implementation and verification (39\%). Regarding creative thinking skills, the highest $\mathrm{N}$-gain was on the indicator of the fluency $(63 \%)$ whereas the lowest was on the indicator of elaboration (39\%). 
Table 5

Improvement for each indicator of problem-solving and creative thinking skills

\begin{tabular}{|c|c|c|c|c|c|c|c|c|c|c|c|c|}
\hline \multirow[t]{2}{*}{ Indicator } & \multicolumn{2}{|c|}{$\begin{array}{l}\text { PBL using } \\
\text { computer } \\
\text { simulation }\end{array}$} & \multirow[t]{2}{*}{$\begin{array}{l}\mathrm{N}- \\
\text { gain } \\
\%\end{array}$} & \multirow[t]{2}{*}{ Criteria } & \multicolumn{2}{|l|}{ PBL } & \multirow[t]{2}{*}{$\begin{array}{l}\mathrm{N}- \\
\text { gain } \\
\%\end{array}$} & \multirow[t]{2}{*}{ Criteria } & \multicolumn{2}{|c|}{ Conventional } & \multirow[t]{2}{*}{$\begin{array}{l}\mathrm{N}- \\
\text { gain } \\
\%\end{array}$} & \multirow[t]{2}{*}{ Criteria } \\
\hline & Pretest & Postest & & & Pretest & Postest & & & Pretest & Postest & & \\
\hline \multicolumn{13}{|c|}{ Problem-solving Skills } \\
\hline $\begin{array}{l}\text { Problem } \\
\text { definition }\end{array}$ & 14.22 & 18.87 & 80 & High & 14.47 & 18.00 & 64 & Medium & 14.72 & 16.97 & 43 & Medium \\
\hline $\begin{array}{l}\text { Generation of } \\
\text { alternatives }\end{array}$ & 13. 62 & 18.91 & 83 & High & 13.78 & 17.31 & 57 & Medium & 13.78 & 16.56 & 45 & Medium \\
\hline $\begin{array}{l}\text { Decision } \\
\text { making }\end{array}$ & 12.75 & 18.41 & 78 & High & 12.53 & 16.94 & 59 & Medium & 13.03 & 16.41 & 48 & Medium \\
\hline $\begin{array}{l}\text { Solution } \\
\text { implementation } \\
\text { and verification }\end{array}$ & 12.19 & 23.16 & 39 & Medium & 11.81 & 19.78 & 28 & Low & 10.75 & 18.31 & 26 & Low \\
\hline \multicolumn{13}{|c|}{ Creative Thinking Skills } \\
\hline Fluency & 13.03 & 23.72 & 63 & Medium & 12.78 & 21.81 & 52 & Medium & 12.78 & 18.22 & 31 & Medium \\
\hline Flexibility & 12. 09 & 23.06 & 61 & Medium & 11.68 & 20.68 & 49 & Medium & 11.91 & 18.15 & 34 & Medium \\
\hline Originality & 10.63 & 14.83 & 44 & Medium & 10.47 & 12.73 & 24 & Low & 10.59 & 13.33 & 29 & Low \\
\hline Elaboration & 8.72 & 13.17 & 39 & Medium & 8.87 & 13.31 & 39 & Low & 8.63 & 11.89 & 28 & Low \\
\hline
\end{tabular}

\section{Multivariate Analysis of Variance (MANOVA)}

Multivariate analysis of variance was performed to analyze pretest and posttest of problem-solving and creative thinking skills. Table 6 shows the relationship between students' problem-solving and creative thinking skills. Findings indicated that there is no significant difference in pretest scores among the three groups on problem-solving and creative thinking skills. However, there were significant differences in posttest scores of problem-solving and creative thinking skills $(p<0.05)$.

Table 6

MANOVA on problem-solving and creative thinking skills

\begin{tabular}{llllll}
\hline Variable & df & Pretest & & Postest & \\
\hline & & $F$ & $p$-value & $F$ & $p$-value \\
\hline Problem-solving & 2 & 0.063 & 0.939 & 25.294 & 0.000 \\
\hline Creative thinking & 2 & 0.037 & 0.964 & 35.142 & 0.000 \\
\hline
\end{tabular}

Further analysis using the post-hoc test in Table 7 reveals that the students in the PBL group using simulations outperformed than the students in the PBL and conventional groups implying that there are positive effects of implementing PBL combined with computer simulations on students' problem-solving and creative thinking skills. 
Table 7

Post-hoc pairwise comparison group on post-test scores

\begin{tabular}{lll}
\hline Group & Average difference & $p$-value \\
\hline Problem-solving skills & & \\
\hline PBL using simulation $v s$ PBL & 7.343 & 0.000 \\
\hline PBL using simulation $v s$ conventional & 11.093 & 0.000 \\
\hline PBL $v$ conventional & 3.750 & 0.057 \\
\hline Creative thinking skills & & \\
\hline PBL using simulation $v s$ PBL & 4.421 & 0.021 \\
\hline PBL using simulation $v s$ convensional & 13.375 & 0.000 \\
\hline PBL $v s$ convensional & 8.953 & 0.000 \\
\hline
\end{tabular}

Relationship between Problem-solving and Creative Thinking Skills

Based on analysis using SPSS for windows, Table 8 displays an interesting result showing a positive correlation between problem-solving and creative thinking skills ( $r$ $(192)=0.986, p<0.01)$. This indicates that the higher the students' problem-solving skills are, the higher their creative thinking skills would be. Furthermore, Figure 2 exhibits the correlation of students problem-solving and creative thinking' scores which also clearly confirms that students with high problem-solving skills have high creative thinking skills.

Table 8

Pearson correlation between problem-solving and creative skills.

\begin{tabular}{llll}
\hline & & Problem-solving & Creative thinking \\
\hline \multirow{3}{*}{ Problem-solving } & Pearson correlation & 1.000 & $0.986^{* *}$ \\
& Sig. (2-tailed) & & .000 \\
& $\mathrm{~N}$ & 192 & 192 \\
\hline Creative thinking & Pearson correlation & $0.986^{* *}$ & 1.000 \\
& Sig. (2-tailed) & .000 & \\
& $\mathrm{~N}$ & 192 & 192
\end{tabular}

**Correlation is significant at the 0.01 level (2-tailed).

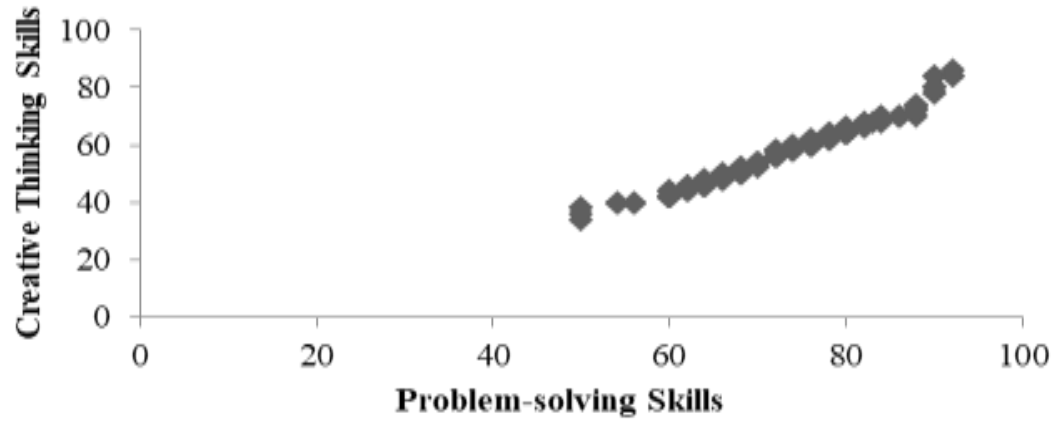

Figure 2

Correlation between problem-solving and creative thinking skills 


\section{DISCUSSION}

Our results showed that students taught with PBL using computer simulations have a significant improvement on students' problem-solving skills as compared to students taught using PBL only and conventional methods. The students taught with PBL using simulation were involved in authentic problems that make them feel curious and think about how to solve the problems. Instruction using PBL combined with simulations provides a lot of opportunities for students to collaborate during the experiment procedures, which have generated more interactions among students and between students and teachers. van Riesen et al. (2018) argued that experiments can lead students to construct their knowledge and help them to eventually solve the problems. In this regard, students become more engaged in such a teaching method as compared to the conventional method. Further, Eersoy \& Baser (2014) stated that knowledge that students gained from PBL-based learning makes them become the problem-solvers using a high-order thinking skill. The findings are also consistent with that in Kadir et al., (2016), in which PBL was suggested as an effective instructional tool for improving students' problem-solving skills. It is crucial to note that the students are more directed at solving problems by involving the computer simulations in teaching and learning. Ersoy \& Başer (2014) found that learning with PBL could make students identify and solve problems with their ideas and abilities and develop their creative thinking. More importantly, they worked in groups to identify what they need to learn and to solve (Savery, 2015). Sahyar, et al., (2017) also showed that PBL could foster students' higher-order thinking skills such as problem-solving, creative thinking, and critical thinking skills. Students' problem-solving skills improve when they are taught using problem-solving method (Wahyu et al., 2017). Our results also demonstrated that the creative thinking skills of students taught with PBL using simulation are outperformed than those taught either PBL only or conventional method. We (authors) argued that this because the phase of PBL combined with simulation leads students to think creatively in order to find solutions to the problems. This result was in line with some earlier studies (Nuswowati, 2017; Siew et al., 2015; Sihaloho, et al. 2017; Ulger, 2016) in which students are more creative in PBL with simulation group than the conventional group. Problem-based learning can support the development of creative thinking skills during the learning process (Birgili, 2015; Ulger, 2016). Gok (2011) stated that students feel more challenged to do their learning, increase understanding of how theory can explain physical observations learning with computer simulations. This is supported by several studies (Arias et al., 2020; Bozkurt \& Ilik, 2010; Sarabando et al., 2014) that using simulation can develop students' understanding of physics concepts. PBL with computer simulation has a positive impact on students' problem-solving skills and creative thinking.

Another finding of this study was the significant correlation between student's problemsolving and creative thinking skills. From the first phase to the final phase of PBL, students were required to practice and exhibit their creative thinking skills to think fluently (fluency) when solving a problem. During this process, students asked many questions to their classmates and the teacher. They also attempted to answer several questions that emerged during the problem-solving process. They also express their 
ideas and work faster in solving the given problem-as compared to conventional learning. Students were trained to showcase authentic thinking to build new ideas and the solution to problems that were not thought of by others. In accordance to the aforementioned concerns, Grégoire (2016) also stated that students who have new ideas could increase their creativity to develop students' original thinking, they should engage in an opportunity to work with problems that are not clear and open (ill-posed and openended problems). Through these experiences, students would be able to develop their creative thinking skills. This is reinforced by Arikan (2017) who argued that students who are able to produce authentic problems have the potential to think creatively. Creative thinking is needed to train children in solving their problems (Kashani-Vahid, et al., 2017). In addition, students are also trained to layout their elaboration in more detail as are required to solve problems through investigation of PBL learning. To arrive at an expected solution, the students are directed to make detailed problem-solving steps and would consequently be able to develop their ideas or the ideas of their peers in a PBL combined with computer simulations group. Based on the description above, we conclude that there is a positive relationship between problem-solving and creative thinking skills. This study confirms the claim in the study of Baructu (2017) which revealed that there is a relationship between problem-solving and creative thinking skills among nursing students. Students' problem-solving skills increase significantly, as creative thinking skills also increase.

\section{CONCLUSIONS AND IMPLICATIONS}

This study shows that PBL using computer simulations could significantly improve students' problem-solving and creative thinking skills. The findings also indicate that PBL with computer simulations in collaborative learning could help students understand problems more comprehensively and develop their creative thinking skills to solve problems. In addition, a significant relationship between problem-solving skills and creative thinking skills does exist. Ultimately, this study would be helpful for teachers when determining or selecting a suitable teaching approach to teach physics, especially the topics of simple harmonic motion, impulse, and momentum. Thus, educational stakeholders may consider implementing PBL combined with computer simulations in the curriculum for senior high schools to improve students' problem-solving and creative thinking skills.

\section{ACKNOWLEDGMENTS}

The authors would like to thank the ministry of education of Indonesia and Rector of the State University of Medan for funding this research under contract: Number 48/UN33.8/PL-DRPM/2019

\section{REFERENCES}

Arias, R., da Cunha, A. P., \& Garcia Ramirez A. R. (2020). Teaching of mechanical vibration concepts using the computational simulation. IEEE Latin America Transactions, 18(4), 659-667.

Arikan, E. E. (2017). Is there a relationship between creativity and mathematical creativity? Journal of Education and Learning, 6(4), 239-253. 
Argaw, A.S., Haile, B.B., Ayalew, T.A., \& Kuma, G.K. (2017). The Effect of Problem Based Learning (PBL) Instruction on Students' Motivation and Problem-solving Skills of Physics. Eurasia Journal of Mathematics, Science and Technology Education, 13, 857-871.

Bao, L. (2006). Theoretical comparisons of average normalized gain calculations. American Journal Physics, 74(10), 917 - 922.

Baructu, C. D. (2017). The relationship between problem-solving and creative thinking skills among nursing students. International Journal of Psychology and Educational Studies, 4(2), 34-41.

Beal, C.R \& Stevens, R. H. (2011). Improving students' problem-solving in a web-based chemistry simulation through embedded metacognitive messages. Tech Inst Cognition and Learning. 8(3-4), 255-271.

Birgili, B. (2015). Creative and Critical Thinking Skills in Problem-Based Learning Environments. Journal of Gifted Education and Creativity, 2(2), 71-80.

Bozkurt, E. \& Ilik, A. (2010). The effect of computer simulations over students' beliefs on physics and physics success. Procedia Social and Behavioral Sciences 2, 45874591.

Ersoy, E \& Başer, N. (2014). The effects of problem-based learning method in higher education on creative thinking. Procedia - Social and Behavioral Sciences, 116, $3494-$ 3498.

Gok, T. (2011). The effects of the computer simulations on students' learning in physics education. International Journal on New Trends in Education and Their Implications, 14(2), 279-289.

Grégoire, J. (2016). Understanding creativity in mathematics for improving mathematical education. Journal of Cognitive Education and Psychology, 15(1), 24-36

Jane, M.W., Wachanga S.W., \& Anditi, Z.O. (2017). Effects of computer-based simulations teaching approach on students' achievement in the learning of chemistry among secondary school students in Nakuru sub county, Kenya. Journal of Education and Practice, 8(5), 65-75.

Jimoyiannis, A., \& Komis,V. (2011). Computer simulations in physics teaching and learning: A case study on students understanding of trajectory motion. Computer \& Education, 36, 183-204.

Kadir, Z. A., Abdullah, N. H., Anthony, E., Salleh, B. M., \& Kamarulzaman, R. (2016). Does problem-based learning improve problem-solving skills? A study among business undergraduates at Malaysian Premier Technical University. International Education Studies, 9(5), 166 - 172.

Kampylis, P \& Berki, E. (2014). Nurturing creative thinking. Switzerland: International Academy of Education, UNESCO.

Kashani-Vahid, L., Afrooz, G. A., Shokoohi-Yekta, M., Kharrazi, K., \& Ghobari, B. (2017). Can a creative interpersonal problem-solving program improve creative thinking in gifted elementary students? Thinking Skill and Creativity, 24, 175-185. 
Koray, Ö. \& Koray, A. (2013). The Effectiveness of Problem-based Learning Supported with Computer Simulations on Reasoning Ability, Procedia - Social and Behavioral Sciences, 106, 2746-2755.

Lee, M.N., Nam, K.D., \& Kim, H.Y. (2017). Effects of Simulation with Problem-Based Learning Program on Metacognition, Team Efficacy, and Learning Attitude in Nursing Students, CIN: Computers, Informatics, Nursing, 35(3), 145-151

Manunure, K., Delserieys, A., \& Castéra, J. (2019) The effects of combining simulations and laboratory experiments on Zimbabwean students' conceptual understanding of electric circuits. Research in Science \& Technological Education, 38(1), 1-19

Makransky, G., Terkildsen, T.S., \& Mayer, R.E. (2019). Adding immersive virtual reality to a science lab simulation causes more presence but less learning. Learning and Instruction, 60, 225-236

Marra, R., Jonassen, D. H., Palmer, B., \& Luft, S. (2014). Why problem-based learning works: Theoretical foundations. Journal on Excellence in College Teaching, 25(3\&4), 221-238.

Mariati, P.S., Betty, M. T., \& Sehat, S. (2017). The problem-solving learning model by using video recording on experiments of kinematics and dynamics to improve the students Cognition and Metacognition. Jurnal Pendidikan Fisika Indonesia, 13(1), 2532.

McHaney, R. (2009). Understanding computer simulation. Ventus Publishing ApS.ISBN 978-87-7681-505-9

Mustofa, R. F., \& Hidayah, Y. R. (2020). The Effect of Problem-Based Learning on Lateral Thinking Skills. International Journal of Instruction, 13(1), 463-474.

Nezu, A. M., Nezu C. M., \& D’Zurilla T.J. (2013). Problem-solving therapy a treatment manual. New York, NY: Springer Publishing Company.

Nuswowati, M., Susilaningsih, E., Ramlawati, \& Kadarwati, S. (2017). Implementation of problem based learning with green chemistry vision to improve creative thinking skill and students' creative action. Jurnal Pendidikan IPA Indonesia, 6(2), 221 - 228.

Putich, K. A. \& Stevens J. P. (2016). Applied Multivariate Statistics for the Social Sciences Analyses with SAS and IBM's SPSS Sixth Edition. New York, NY: Routledge.

Rahmawati, Y. \& Taylor, P. C. (2019). Empowering Science and Mathematics for Global Competitiveness. London: CRC Press

Rutten, N., van Joolingen, W.R., \& van der Veen, J.T. (2012) The learning effects of computer simulations in science education, Computers \& Education, 58(1), 136-153.

Sahyar, Sani, R.A., \& Malau, T. (2017). The effect of problem based learning (PBL) model and self regulated learning (SRL) toward physics problem-solving ability (PSA) of students at senior high school. American Journal of Educational Research, 5(3), 279283.

Sarabando, C., Cravino, J., \& Soares, A., (2014). Contribution of a Computer Simulation to Students' Learning of the Physics Concepts of Weight and Mass. Procedia Technology, 13, 112-121. 
Savery, J.R. (2015). Essential Readings in Problem-Based Learning: overview of problem-based learning: definitions and distinctions. United States, US: University Press.

See, Y. G., Rashid, A. M., \& Bakar, A. B., (2015). The Effect of Project Based Learning on Level of Content Knowledge of Pre-Vocational Subject. Mediteranean Journal of Social Sciences, 6(6), 369-375.

Siew, N. M., Chong, C.L., \& Lee, B. N. (2015). Fostering fifth grades' scientific creativity through problem based learning. Journal of Baltic Science Education, 14(5), $655-669$.

Shisigu, A., Hailu, A., \& Anibo, Z. (2018). Problem-based learning and conceptual understanding of college female students in physics. Eurasia Journal of Mathematics Science and Technology Education, 14(1), 145-154.

Sihaloho, R.R., Sahyar \& Ginting, E.M. (2017). The effect of problem based learning (PBL) model toward student's creative thinking and problem-solving ability in senior high school. IOSR Journal of Research \& Method in Education (IOSR-JRME), 7(4), 11-18.

Sulaiman F., (2013). The Effectiveness of PBL Online on Physics Students' Creativity and Critical Thinking: A Case Study at Universiti Malaysia Sabah. International Journal of Education and Research, 1, 1-18.

Syaibani, H. A., Dafik, \& Hobri. (2017). The Analysis of Student's Creative Thinking Skills in Solving "Rainbow Connection" Problem through Research Based Learning. The International Journal of Social Sciences and Humanities Invention. 4(8), 37833788.

Tambade P. S. (2011). Use of spreadsheet for the perturbation theory in quantum harmonic oscillator. European Journal of Applied Sciences, 3(4), 117-124.

Ulger, K. (2016). The relationship between creative thinking and critical thinking skills of students. H.U. Journal of Education, 31(4), 695-710.

Ulukök, S., \& Sari, U. (2016). The Effect of Simulation-Assisted Laboratory Applications on Pre-Service Teachers' Attitudes towards Science Teaching. Universal Journal of Educational Research. 4(3), 465-474.

van Riesen S. A. N., Gijlers, H., Anjewierden, A., \& de Jong, T. (2018). The influence of prior knowledge on experiment design guidance in a science inquiry context, International Journal of Science Education, 40(11), 1327-1344.

Vlachopoulos, D., \& Makri, A. (2017). The effect of games and simulations on higher education: a systematic literature review. International Journal of Educational Technology in Higher Education, 14(22), 1-33.

Wahyu, E. S., Sahyar, \& Ginting, E. M. (2017). The effect of problem based learning (PBL) model toward student's critical thinking and problem-solving ability in senior high school. American Journal of Educational Research, 5(6), 633-638.

Wanya, C.S. (2016). Performance and determinants of problem-solving among college physics students. International Journal of Advanced Research in Management and Social Sciences, 5(6), 830-854. 